\title{
"I WANT THIS FIRM TO BE IN GOOD HANDS": EMOTIONAL PRICING OF RESIGNING ENTREPRENEURS
}

\author{
Nadine Kammerlander \\ University of St.Gallen \\ Dufourstrasse 40a \\ 9000 St.Gallen, Switzerland \\ nadine.kammerlander@unisg.ch \\ phone: +41 712247116
}

\section{Paper forthcoming in International Small Business Journal \\ Special Issue on Entrepreneurial Exit, Guest edited by K. Wennberg and Dawn DeTienne}

Acknowledgements:

This manuscript greatly benefitted from comments of Guest Editor Karl Wennberg as well as three anonymous reviewers. I gratefully acknowledge the support and comments of Miriam Bird, Martin Carlsson-Wall, Andreas Christen, Dawn DeTienne, Melanie Ganter, Frank Halter, Thomas Hjelström, Manuela Merki, and Thomas Zellweger as well as participants of the 2013 State of the Field Entrepreneurial Exit Conference in Stockholm, Sweden. A prior version of this manuscript received the 2014 Transeo Best Academic Paper Award. This study was embedded in a large-size research project that received financial support from Credit Suisse, Switzerland. 


\title{
"I WANT THIS FIRM TO BE IN GOOD HANDS": EMOTIONAL PRICING OF RESIGNING ENTREPRENEURS
}

\begin{abstract}
Given the importance of non-economic considerations throughout the entrepreneurial life cycle, I aim to investigate the drivers of owner-managers" "emotional pricing" when they wish to sell their firms to successors. Emotional pricing thereby denotes those elements of the ownermanagers' price expectations that cannot be traced back to economic considerations. Building on arguments from behavioral finance, I hypothesize that "emotional pricing," which in this study reflects owner-managers' willingness to sell the firm at a discount, is driven by the reluctance to lose access to information about the firm and to lose influence on the firm, and by an aversion to putting the firm's future at risk. In particular, I argue that a long-term relationship between an owner-manager and a firm, a familiar relationship between an owner-manager and a successor, and situational contingencies_-especially unsatisfactory firm performance-increase the ownermanager's emotional-pricing component. I test the hypotheses using a sample of 1,354 ownermanagers of Swiss SMEs, who provided their views on their exit intentions. I subsequently compare those results to 455 actual ownership transfers involving Swiss SMEs.
\end{abstract}

Keywords: entrepreneurial exit, emotional pricing, behavioral finance, loss aversion, exit route 


\section{Introduction}

For almost all entrepreneurs, exiting the business is a major event with important implications for the owner-manager, the firm, and the firm's stakeholders (DeTienne, 2010; Wennberg et al., 2011). As an emerging stream of research has revealed, this process is not only influenced by economic but also non-economic considerations of the resigning owner-manager (e.g., Cardon et al., 2005b; DeTienne, 2010; DeTienne and Chirico, in press; Wennberg and DeTienne, 2014). In this context, scholars argue that owner-managers feel emotionally attached to their firm (DeTienne, 2010; Dehlen et al., 2014), that they strongly identify with the business (Zahra, 2003), and that they even care about its post-exit prosperity (Graebner and Eisenhardt, 2004).

Despite those recent advancements, research on the antecedents of such non-economic considerations is still limited. This is an important gap in literature, as non-economic considerations affect the exiting owner-managers' intentions and decision making, and, as a consequence, may also affect the owner-manager's satisfaction in the exit process and the overall success of that process. For instance, owner-managers with strong (as compared to weak) emotional attachments to their firms are significantly less likely to transfer their businesses to individuals outside the family (Dehlen et al., 2014), even though the external exit path has been shown to result in superior firm performance (Wennberg et al., 2011).

In order to help close this gap in the extant literature, I theorize and test how several important antecedents influence owner-managers' non-economic considerations with regard to a central aspect of the entrepreneurial exit process: the intended pricing of the firm. As a sale of the firm is among the most common exit options (Dehlen et al., 2014; Howorth et al., 2007; Battisti and Okamuro, 2010), owner-managers' price expectations are particularly relevant (Granata and Chirico, 2010). The underlying assumption is that owner-managers' price expectations determine important "exit outcomes" (Van Teeffelen and Uhlaner, 2013: 2), 
including the speed of the transaction process and the satisfaction of the parties involved. In fact, such expectations are likely to play a key role in determining whether a transfer of the business takes place at all (Howorth et al., 2004; Geerts et al., 2004).

To advance theory on non-economic considerations in the entrepreneurial exit process, in particular to deduce hypotheses on the antecedents of non-economic pricing considerations, I build on arguments found in behavioral finance (Shleifer, 2000; Barberis and Thaler, 2003). Behavioral finance offers an appropriate theoretical lens for this study, as it allows for theorizing about how decision making is influenced by non-economic considerations in situations characterized by uncertainty (Ariely et al., 2005). In contrast to neoclassical finance theories, behavioral finance includes sellers' economic and non-economic considerations, and it emphasizes humans' general desire to avoid losses (Kahneman and Tversky, 1979). In particular, behavioral finance has long emphasized the important role of temporal aspects (Carmon and Ariely, 2000), trust (Olsen, 2012), and sellers' framing (Barber and Odean, 2000) in sales situations. Those factors have also been studied extensively in entrepreneurial research since any exit consideration of a resigning owner-manager needs to be viewed in light of his or her relations with other stakeholders (Dehlen et al., 2014) and also in light of the firm's financial situation (Wennberg et al., 2010). Therefore, this study focuses on the effects of the relationship between the owner-manager and his or her firm (Pierce et al., 2001) and the relationship between the owner-manager and his or her successor (Van Teeffelen et al., 2011). It also focuses on firm performance as an important determinant (Stam et al., 2010).

I thus aim to answer the following specific research question: How do (a) the ownermanager's tenure, (b) the level of familiarity between the owner-manager and the successor, and (c) (pre-transfer) firm performance, as perceived by the owner-manager affect the ownermanager's emotional pricing in the context of an intended firm sale? 
I thereby define "emotional pricing" as those elements of the resigning owner-manager's sales price expectations that relate to his or her non-economic instead of economic considerations. More specifically, in this study, emotional pricing reflects the owner-manager's intention to sell the firm at a discount to its actual market value. In particular, I argue that as the tenure of owner-manager increases, as the owner-manager becomes increasingly familiar with the successor, and when the firm shows inferior performance, owner-managers become more willing to offer a discount on the firm's estimated market price. I test the hypotheses using a survey of 1,354 owner-managers of Swiss small and medium-sized enterprises (SMEs) who have already considered their own (future) exits from their businesses. I also use a sample of 455 actual SME transfers (from incumbent owner-managers to their successors) that occurred within the last decade in Switzerland since intentions do not necessarily translate into actions.

This research advances the emerging stream of literature on entrepreneurial exits in multiple ways. First, this study adds to our knowledge about the role of non-economic considerations in the entrepreneurial exit process (see e.g., studies by DeTienne, 2010; Cardon et al., 2005b; DeTienne and Chirico, in press). By shifting the focus of analysis from the mere existence of non-economic considerations to their antecedents, this study extends and deepens our understanding of the entrepreneurial exit process. A second, theoretical, contribution lies in the continuation and extension of prior work (Wennberg et al., 2010) that has started to establish theory on behavioral finance to explain entrepreneurial exit phenomena. The findings presented here not only confirm the importance of behavioral aspects for entrepreneurial exit intentions but also emphasize the importance of non-financial losses (such as control and access to information) for resigning owner-managers. While loss aversion (i.e. a human beings' strong preference for avoiding any losses, which outweighs potential future gains in decision making) with regard to owners' control over the firm is well established in other research streams (Gómez-Mejía et al., 
2007; Chrisman and Patel, 2012), it has not previously been incorporated into the entrepreneurial exit literature. In addition, from an empirical view, this study offers additional support for the notion that owner-managers care about the post-transfer prosperity of their firm (Graebner and Eisenhardt, 2004; DeTienne, 2010). Finally, this study is first to draw scholarly attention to the construct of "emotional pricing," which is a consequence of owner-managers" loss aversion and which has been largely overlooked despite its importance for the overall success and satisfaction of all parties involved in a business transfer.

\section{Theoretical Foundations}

\subsection{Entrepreneurial Exits and Pricing Aspects}

All owner-managers must exit their businesses at some point. However, they differ with regard to why they resign (DeTienne, 2010) and how they do so (Wennberg et al., 2010). When exiting their business, incumbent owner-managers can either discontinue the business (liquidation); issue shares to the public (IPO); or sell the business to family members (family buyout, FBO), employees (management buyout, MBO), external individuals (management buy-in, MBI), or other firms (acquisitions). As this study aims to investigate the non-economic aspects of owners' considerations when intending to sell the firm to another party, I focus on the last four exit paths, which all include sales of the firm. This approach is also in line with empirical findings that show that a sale of the business is, by far, the most dominant exit choice among SMEs (Howorth et al., 2004; Battisti and Okamuro, 2010; Coad, 2013). Furthermore, although entrepreneurial exits constitute a dyadic setting that involves the perspectives of the incumbent and the successor, this paper focuses on the perspective of the incumbent owner-manager, which is underinvestigated in the extant entrepreneurship research (Graebner and Eisenhardt, 2004; Wennberg et al., 2010). 
Agreement on the transaction price is at the core of an entrepreneurial exit process, as it can be decisive for the success of the intended exit (Scholes et al., 2007) and as it affects the level of satisfaction with the process (Niedermeyer et al., 2010). However, determining adequate transaction prices for private firms, especially SMEs, is difficult (Baik et al., 2007). No commonly agreed approach exists for calculating the value of an unlisted firm. Researchers and practitioners can choose from a variety of methods, including multiple-based approaches, income-based approaches, and asset-based approaches (Feldman, 2005; Pratt et al., 2000). These approaches often result in different calculations of the firm's estimated real value. ${ }^{1}$ Therefore, a basic assumption adopted in this paper is that the resigning owner-manager has basic knowledge about the real value of the firm, regardless of what that figure is in absolute terms (and regardless of how well the owner-manager's perception of the real value fits experts' perceptions of the real value). This assumption is reasonable, as I focus on resigning owner-managers who have already thoroughly considered their future exits, and as certain valuation methods, such as the multiplebased approach, allow owner-managers to quickly assess the rough value of their businesses without requiring substantial effort or knowledge (Granata and Chirico, 2010).

Empirical evidence reveals that many privately held firms are not sold for their actual value. Instead, they are traded at a discount in the two-digit percentage area relative to similar publicly listed companies (Officer, 2007; Cooney et al., 2009). Part of this discount might be attributable to buyers' malevolent assessments and their superior negotiation skills (Granata and Chirico, 2010). However, findings on such discounts may also serve as preliminary indication that exiting owner-managers are driven not only by economic considerations, such as the maximization of the transaction price, but also by non-economic considerations.

\subsection{Behavioral Finance and Emotional Pricing}

\footnotetext{
${ }^{1}$ Each of those approaches has several advantages and disadvantages. Throughout this paper, I use the term "real value" without specifying the exact calculation method.
} 
To hypothesize on the determinants of resigning owner-managers' emotional pricing, I build on theory of behavioral finance, which has recently been shown to be promising to explain entrepreneurial exit phenomena (Wennberg et al., 2010). Behavioral finance aims to explain the buying and selling behaviors of individuals (Barberis and Thaler, 2003). It thereby assumes that individuals do not strive to maximize their profit but rather to maximize their utility function, which might include non-economic considerations. Moreover, assuming bounded rationality (Cyert and March, 1963) and building on prospect theory (Kahneman and Tversky, 1979), behavioral finance claims that sellers' decisions are typically characterized by high levels of affection (Odean, 1998). More specifically, it claims that an individual's decision making is driven by potential gains and losses, rather than the absolute wealth position (Kahneman and Tversky, 1979). The concept of "loss aversion" highlights the human tendency to overemphasize potential losses (as compared to achievable gains) in decision making (Tversky and Kahneman, 1991).

While most research conducted in the field of behavioral finance focuses on buyers and sellers active on stock markets, some recent studies emphasize the applicability of behavioral finance theory to other contexts, such as house sales (Genesove and Mayer, 2001). Building on Gimeno's (1997) work on entrepreneurs' reference points, behavioral finance has been proven promising for explaining entrepreneurial exit phenomena. For instance, a recent study aims to explain why older owner-managers prefer a sale rather than continuation or liquidation due to different considered time horizons (Wennberg et al., 2010). Behavioral finance thereby serves as appropriate theoretical lens, since entrepreneurial exits can be seen as "as liquidation of a financial investment" (Wennberg et al., 2010: 363). Moreover, arguments based on behavioral theories are appropriate for explaining entrepreneurial exits, as the underlying theory—prospect theory—is a "theory of choice under uncertainty in one-shot games" (Kyle et al., 2006: 284). 
This applies for most entrepreneurial exits, as owner-managers typically do not have perfect information about the implications of their decisions, such as the firm's future prosperity, and many of them only resign once or few times from a business (Plehn-Dujowich, 2010).

Owner-managers' loss aversion in entrepreneurial exit situations is a multi-faceted phenomenon. I argue that exiting owner-managers typically not only expect a financial gain but also fear the loss of control over their firm and the potential future discontinuation of their business. I build on prospect theory to argue that those (non-financial) losses often outweigh potential financial gains and are, therefore, of key importance in the resigning owner-managers' decision making. As such, they also influence the owner-managers' emotional pricing considerations. This broad perspective on gains and losses, which encompasses non-financial, "intangible" losses, has not been extensively discussed in the field of behavioral finance. However, this view is well established in other research streams. For example, family-firm owners are known to fear a loss of control over their firm, and they strive for transgenerational continuation of their businesses (e.g., Berrone et al., 2012; Gómez-Mejía et al., 2007).

In particular, I will focus on three important determinants of emotional pricing in the remainder of this manuscript: (a) an owner-manager's management tenure which affects his or relationship to the firm, (b) the level of familiarity between an owner-manager and a successor, and (c) subjective firm performance. Tenure is considered as an important determinant since it captures temporal aspects. Prior literature on behavioral finance states that human beings' attachment to objects develops with time of possession and that such "endowment effect" impacts pricing considerations (Carmon and Ariely, 2000). This is also in line with arguments from entrepreneurial exit research that propose particularly high levels of attachment for long-tenured owner-managers (DeTienne, 2010). Moreover, building on bounded rationality, it has been argued that long tenures lead to myopic, and thus less rational, decision making (König et al., 
2013; Hambrick, 2007). The level of familiarity between owner-manager and successor is an important determinant, since recent findings of behavioral finance studies point to the importance of interpersonal factors such as trust between buyer and seller: Trust affects individuals' risk perceptions and ultimately pricing considerations (Olsen, 2012). Trust, on the other hand, is closely linked to familiarity since it builds up across time (Gulati, 1995). Also entrepreneurial exit literature shows evidence that the level of familiarity between owner-manager and successor is important in entrepreneurial exits, for instance because of information asymmetries (Dehlen et al., 2014). One central aspect of prospect theory (Kahneman and Tversky, 1979) and subsequently also behavioral finance is the seller's framing of a situation as either "gain" or "loss" (Barberis and Thaler, 2003). As a consequence, it might be of great relevance for the posed research question, whether the owner-manager assesses the firm's performance as being above or below the reference point (Wennberg et al., 2010). In line with this reasoning, previous studies have shown that prior performance as compared to an aspiration level is an important determinant of decision making in business settings, for instance regarding innovation (Greve, 2003), divestitures (Shimizu, 2007), or engagement in corporate illegality (Mishina et al., 2010).

\section{Development of Hypotheses}

\subsection{The Owner-Manager's Relationship with the Firm and Emotional Pricing}

I argue that the owner-manager's tenure in the firm is likely to be related to the extent of the noneconomic loss that the owner-manager associates with the potential sale of the firm. Moreover, I suggest that, consequently, the owner-manager's level of emotional pricing is likely to depend on the length of his or her tenure.

This argument is based on the claim that owner-managers are emotionally attached to their firms (DeTienne, 2010). Such attachments mean that owner-managers are likely to view their business as their "babies" and to care about what will happen to the business after their exit 
(Cardon et al., 2005b). Empirical evidence indeed reveals that the responsibility an ownermanager feels for the firm does not dissipate at the time of transfer. As owner-managers care about their firms' futures, they carefully consider their successors (e.g., Dehlen et al., 2014; Graebner and Eisenhardt, 2004), and they experience feelings of grief in case of firm failure (Shepherd et al., 2009; Jenkins et al., 2014). As further consequence of such attachment to the firm, retired owner-managers strive to remain informed about their former businesses and attempt to continue influence those businesses (Sharma et al., 2003; Quigley and Hambrick, 2012).

The emotional attachment of owner-managers is related to the attention they pay to noneconomic considerations in their exit decisions. For any emotionally attached owner-manager, a firm failure, or the lack of information and influence after an exit, are perceived as non-economic losses that they wish to avoid. Behavioral finance theory (Barberis and Thaler, 2003) suggests that an owner-manager will be willing to compromise on the (financial) gains associated with the entrepreneurial exit in order to mitigate the (non-economic) losses . In other words, a high transaction price becomes a subordinate goal, and the owner-manager is likely consent to a financial discount to a successor who will continue the firm's operations in a way that the incumbent owner-manager perceives as desirable.

However, owner-managers' ties to their firms change over time (DeTienne, 2010). As the duration of ownership and management responsibility increases, the owner-manager's emotional attachment to the business grows (Dehlen et al., 2014; Zellweger et al., 2012) because the ownermanager increasingly identifies with the business (Zahra, 2003; Stryker and Burke, 2000; Hsu, 2013). This temporal effect is in line with findings from research on endowment effects undertaken by behavioral economists (Knetsch, 1989) and with predictions on psychological ownership (Pierce et al., 2001). Therefore, among owner-managers who have served their companies for an extended period of time, the dominance of non-economic considerations should 
be even greater due to the increased emotional attachment to the firm and the time and effort invested in the firm. As a consequence of this increased emotional attachment, I expect that the owner-manager's willingness to sell the business at a discount and his or her focus on realizing an exit option that minimizes his or her perceived non-financial losses grows as his or her time at the helm of the company increases. Formally, I propose:

H1: The owner-manager's entrepreneurial tenure is positively related to emotional pricing, which takes the form of a discount offered to the successor.

\subsection{The Owner-Manager's Relationship with the Successor and Emotional Pricing}

Regarding the relationship between incumbent owner-manager and successor, I suggest that the familiarity between the two parties (Van Teeffelen et al., 2011) and thus the targeted exit path is related to the owner-manager's loss perceptions associated with his or her exit. In particular, I argue that the expected non-economic losses associated with the owner-manager's exit depend on whether the business is sold to family members, firm employees, family- and firm-external individuals, or other firms. Each of these exit types (Parker et al., 2010) is characterized by a certain level of "closeness" or familiarity between the owner-manager and the successor. While family members are closest due to their extended interactions over time, often also in private settings, relationships with employees, external individuals, or other firms are characterized as increasingly distant.

I argue that the owner-managers' expected non-financial losses are less salient if he or she is close to the successor for two reasons. First, the owner-manager's level of trust in the successor's capabilities to shape the firm's future in a positive way is likely to vary (Howorth et al., 2004; Van Teeffelen et al., 2011; Morris and Williams, 1997). In general, trust depends on the history of exposure to a certain person and it typically grows over time (Johnson-George and Swap, 1982). As a consequence, human beings, ceteris paribus, typically have greater trust in individuals who are closer and more familiar to them, such as family members, than in strangers 
(Luo and Chung, 2005). If owner-managers know and trust the person to whom they plan to transfer the business, they will be more confident that the individual will continue the business operations in a desirable and successful way, thereby avoiding the firm's failure. This line of argumentation is in line with findings that owner-managers who strive for long-term continuation of the business (Chua et al., 1999) prefer family-internal succession - the transfer of the firm to the most familiar individuals - in order to avoid the loss of legacy, tradition, and socio-emotional wealth (Gómez-Mejía et al., 2007; Zellweger et al., 2012). The role of trust has also recently been emphasized by behavioral finance scholars (Olsen, 2012) as well as in the context of SMEs (Geneste and Galvin, 2013).

Second, the closer the incumbent is to the successor, the higher the likelihood that the former owner-manager can remain "informed" about the business's activities. In such situations, the former owner-manager might even be able to influence the development of the business, for instance by taking on an advisory role (Osborne, 1991). Therefore, an owner-manager who is highly familiar with the successor should anticipate less loss of control and influence.

In summary, the transfer of the business to a familiar successor allows the owner-manager to minimize the perceived non-financial losses associated with the firm's transfer. In order to achieve such loss mitigation — which is a principal goal of individuals according to prospect theory (Kahneman and Tversky, 1979)—, I suggest that resigning owner-managers intend to offer a discount in the transaction price. In other words, the owner-manager will be willing to accept a lower transaction price for the business if he or she feels confident that the firm will be continued in a desirable way, and that there will be ongoing opportunities to remain informed about the company and influence its development. Formally, I propose:

H2: Familiarity between the successor and the incumbent is positively related to emotional pricing, which takes the form of a discount offered to the successor.

\subsection{Perceived Firm Performance and Emotional Pricing}


Building on prior insights on the important role of the firm's performance, especially relative to the owner-manager's aspirations, in the entrepreneurial exit process (e.g., DeTienne and Chirico, in press; Wennberg et al., 2010), I propose that unsatisfactory performance gives rise to a fear that the firm will ultimately fail and, thus, enhances the owner-manager's willingness to sell the firm at a substantial discount to its real value.

When the owner-manager assesses firm performance as low relative to peers, he or she is likely in a "distress" situation (Wennberg et al., 2010). In behavioral finance terms, such managers find themselves in a loss-framing mode. In such a situation, the avoidance of liquidation might become a salient goal because, from the owner-manager's perspective, the discontinuation of the business might be the ultimate failure and the greatest conceivable loss (Bane and Neubauer, 1981; Ucbasaran et al., 2010). Behavioral finance suggests that the utility function for losses is steeper than for gains (Barber and Odean, 2000). I argue that in trying to avoid this type of loss, the importance of other goals, such as achieving a transaction price close to or even above the firm's real value, is likely to fade. This argumentation is also in line with previous general management research showing that decision makers in organizations are "sequentially attentive," such that they pursue goals in sequence rather than simultaneously (Greve, 2008). Consequently, I argue that an owner-manager who is reluctant to realize the perceived non-financial loss will be willing to make tradeoffs with regard to the transaction price as long as the business is likely to be continued.

However, when firm performance exceeds the owner-manager's aspirations, the level of threat of non-economic losses is comparatively lower. In such a situation, the firm's continued existence is not at stake from the owner-manager's own perspective, and the need to quickly find a successor decreases. In such cases, considerations about potential financial gains are likely to become more important, and the incumbent owner-manager might be encouraged to search for a 
successor who is willing to pay a transaction price that is close to or even above the firm's real value. Ceteris paribus, I therefore expect the owner-manager's framing of the exit as loss or gain, which depends on the owner-manager's perception of firm performance, to affect his or her expectations for the transaction price. In sum, I propose:

H3: An owner-manager's perception of inferior firm performance is positively related to emotional pricing, which takes the form of a discount offered to the successor.

\section{Methodology}

\subsection{Research Design and Sample}

To test the hypotheses, I collected survey responses from owner-managers of Swiss SMEs, where SMEs were defined as firms with less than 250 employees. For this purpose, I obtained the addresses of 36,699 owner-managers of privately held Swiss SMEs from the D\&B database. I a priori excluded businesses active in the agriculture, forestry, petroleum refinement, electricity and gas supply, water treatment, financial services, insurance, and public administration sectors (NOGA codes $01,02,19,35,36,64,65,66,84)$ owing to the idiosyncratic characteristics of those sectors.

In January 2013, I sent a cover letter and an eight-page questionnaire to the 36,699 identified owner-managers by regular postal mail. The letter and the questionnaire were written in German, French, or Italian, depending on the postal code of the target company. I received 2,362 completed surveys during the seven-week data-collection phase, which resulted in a response rate of at least $6.4 \%{ }^{2}$. This is slightly lower than that of other studies targeting entrepreneurs or top managers (Cruz et al., 2010; Dehlen et al., 2014; Schulze et al., 2001). The relatively low response rate was most likely attributable to the length of the questionnaire, which required approximately 30 minutes to complete. This length was deemed necessary owing to the

\footnotetext{
${ }^{2}$ The letters that could not be delivered for various reasons, such as incorrect addresses, are not included in the response-rate calculation.
} 
comprehensive nature of the questionnaire, which was embedded in a larger study of Swiss SMEs. ${ }^{3}$ In order to check for non-response bias, I compared the responses of early and late responders on the assumption that late responders resembled non-responders (Oppenheim, 1966). A test for distortion among non-responders was particularly important due to the low response rate. However, the results revealed no significant differences for any of the variables included in the model.

I excluded all surveys that fulfilled at least one of the following criteria: (a) respondent was not the owner-manager of the respective company (six cases), (b) the responding company had more than 500 employees (18 cases), (c) information on the owner-manager's expectations for the transaction price was missing (for instance, the owner-manager may not have contemplated an exit $)^{4}$ (919 cases), and (d) the owner-manager indicated that his or her intended exit strategy was an IPO (11 cases) or liquidation (54 cases), rather than a sale. As a result, the final sample contained 1,354 survey responses ("prospective sample”).

Furthermore, I relied on a subsample of 523 respondents for a post-hoc test of the hypotheses based on actual transactions. These respondents provided information in a separate section of the questionnaire on their own experiences in a role as successor within the previous 10 years ("retrospective sample"). After removing cases with missing data regarding the dependent variable (actual transaction price as a percentage of the real value), this final sample included 455 responses.

In line with other studies on privately held firms, the study utilized the key informant approach (Kellermanns et al., 2008; Kumar et al., 1993; Seidler, 1974), which is reasonable because transaction price expectations and performance perceptions are often known only to the

\footnotetext{
${ }^{3}$ As the research design was based on the physical rather than electronic mailing of the questionnaire to ownermanagers, I was unable to use follow-up emails to increase the response rate.

${ }^{4} \mathrm{I}$ included a filter question in order to assess whether the owner-manager had already contemplated his or her exit strategy.
} 
owner-manager. To assess the degree to which the sample was representative of the total population of Swiss SMEs, I compared the descriptive characteristics of owner-managers and firms in the (prospective) sample with the corresponding characteristics of samples used in comparable studies. The average age of the firms in the sample (44 years) is lower than the average age of the firms in a sample of Swiss family businesses studied by Zellweger et al. (2012) (67 years) and older than the average age of the firms in a sample of startups included in the 2007 Global Entrepreneurship Monitor's (GEM) report on Swiss firms (17 years) (Volery et al., 2007). This is reasonable, as the focus of this study is on established family and non-family firms. The average age of the owner-managers in the sample ( 57 years) is higher than the average ages of the owner-managers of the Swiss firms in the GEM reports (46 years) and of the firms studied by Zellweger et al. (2012) (51 years). This can be explained by the fact that the sample encompasses only answers provided by owner-managers who have already thought about their own exits. Such considerations typically occur towards the end of one's professional career. The descriptive data (Table 1) reveal that the average management tenure of owner-managers in the sample is 20 years. Of the firms in the sample, $84 \%$ are family owned. The average firm in the sample has 36 employees.

Next, I assessed the likelihood of common method bias, which can stem either from a reliance on the same source when measuring the independent and the dependent variables, or from specific item characteristics that enhance respondents' tendencies to answer the survey questions in a distorted, for instance socially desirable, way. When collecting the data, I took several ex ante procedural steps to mitigate the risk of this type of error. First, I designed the questions to be simple and precise (Podsakoff et al., 2003). For this purpose, the language used in the questionnaire was adapted to the target group (owner-managers of Swiss SMEs), and a group of five practitioners independently checked the comprehensibility of the questions and 
suggested slight adaptations. I avoided the use of double-barreled questions, complex syntax, and scientific terms likely to be unfamiliar to the targeted respondents (Podsakoff et al., 2003). Moreover, I asked specific (e.g., "For how much do you aim to sell...?") rather than abstract (e.g., "Please evaluate your emotional-pricing component...”) questions.

Second, the questionnaire was embedded in a comprehensive survey on the economic relevance of entrepreneurial exits in Switzerland. The design of the survey and the order of the questions within the questionnaire did not provide respondents with any indication of the expected correlations. Therefore, the respondents were unlikely to "edit their responses to be more ... consistent with how they [thought] the researcher want[ed] them to respond" (Podsakoff et al., 2003: 888).

Third, I assured the respondents of the strict confidentiality of their responses. This ex-ante measure is known to reduce the probability of social desirability bias in respondents' answers (Podsakoff et al., 2003).

In order to verify ex post that my procedural efforts to reduce common method variance were effective, I performed a single-factor test (Podsakoff and Organ, 1986). An exploratory factor analysis of all of the variables used in this study revealed six factors with eigenvalues greater than 1.0 that jointly accounted for $63 \%$ of the total variance, with the first factor accounting for less than $17 \%$ of the total variance. In sum, the results of the post-hoc analysis together with the various ex ante precautions indicate that common method variance is unlikely to distort the results (Podsakoff et al., 2003).

\subsection{Variables}

\subsubsection{Dependent Variable-Transaction price Expectations}

To assess the owner-managers' transaction-price expectations, I asked the respondents to indicate the target price for the sale of their firm as a percentage of the real value. The respondents could 
choose from one of eight categories: 0\% (1), 1-20\% (2), 21-40\% (3), 41-60\% (4), 61-80\% (5), $81-99 \%(6), 100 \%(7)$, more than $100 \%(8)$. Those transaction-price expectations can be easily transformed into the emotional pricing component, as the transaction-price expectation equals 1 minus emotional pricing.

I asked for relative data on transaction-price expectations rather than for absolute numbers, an approach chosen for instance by Zellweger and colleagues (2012), because relative data is generally considered to be less sensitive. As a consequence, survey respondents are more likely to provide comprehensive and correct relative data on the specific topic. Moreover, relying on absolute rather than relative numbers does not increase the richness and/or correctness of the collected data. More specifically, as there is a lack of information on Swiss SMEs' financial figures, it is impossible to calculate firm values based on externally available data. The decision to ask for information on discounts is in line with other studies in related areas, such as those focused on real-estate sales (Wong and Hui, 2008).

\subsubsection{Independent Variables}

Financial performance. As the arguments in this study are based on behavioral theories and refer to the owner-managers' perceptions of firm performance, I used a subjective measure of firm performance. In line with previous research (e.g., Deshpandé et al., 1993; Reinartz et al., 2004; Zellweger et al., 2012), I asked respondents to indicate their assessment of their firms' financial performance relative to that of competitors in the previous three years. Respondents were asked to use a seven-point Likert scale ranging from "much worse" (1) to "much better" (7) to assess performance in terms of profit, revenue growth, market-share growth, and profitability growth (Zellweger et al., 2012). I used the mean of the four items as an indicator of perceived financial performance. 
Tenure. To assess the owner-manager's tenure, I asked the respondent to indicate in which year he or she took on the responsibility of managing the firm. The variable "tenure" was calculated by subtracting the indicated year from the year in which this study was conducted (i.e. 2013) and thus indicates the number of years the owner-manager has been responsible for the organization (see e.g., Naldi et al., 2013; Huybrechts et al., 2013). As an analysis of a subsample with available data on ownership tenure - a variable often argued to correlate with emotional attachment (Zellweger and Astrachan, 2008; Zellweger et al., 2012)_reveals, the time of taking over management responsibility often converged with taking over ownership.

Familiarity with the successor. To operationalize the owner-manager's familiarity with the future successor, respondents were asked to indicate to whom they planned to transfer the ownership of their firm at the time of their exit. In line with prior research (for an overview see Wennberg and DeTienne, 2014), respondents could choose among six exit options: sale to a family member(s) (FBO), sale to employees (MBO), sale to an external person(s) (MBI), sale to another business (sale to a firm), liquidation, or IPO (respondents who chose liquidation or IPO were excluded from the analysis, as described in subchapter 3.1). In terms of familiarity, I assumed that family members were the closest, and that family- and firm-external individuals (MBI and sale to a firm, respectively) were most distant. I dummy coded these variables, using "still unknown/unsure" as reference category. The use of four independent dummy variables is preferable to treating incumbent-successor familiarity as an ordinal variable, as the effects of exit-path types on the dependent variables are not necessarily even (Hamidi et al., 2008).

\subsubsection{Control Variables}

I included eight control variables that could affect the owner-manager's emotional-pricing component. First, I included a dummy variable indicating co-ownership (= 1 if owner-manager had less than $100 \%$ ownership shares, or 0 otherwise), since the presence of several owners could 
alter transaction-price expectations. Second, I included a dummy variable that indicated whether the business was a family business $(=1$, or 0 otherwise). Emotional attachment to the business is high in family firms (Zellweger et al., 2012), which might impact the incumbent's transactionprice expectations. Third, I controlled for industry-induced effects by applying a dummy variable ( 1 for tertiary sector, 0 for secondary sector). Fourth, I included firm size, which I measured as the number of full-time employees. When financial performance is below the owner-manager's target, owner-managers of larger firms might be more anxious to find a successor due to the financing issues inherent in the transfer of larger businesses to one or more individuals (Dehlen et al., 2014). Fifth, I included a dummy variable indicating whether the owner-manager was the founder of the firm ( $=1$, or 0 otherwise) because the decision-making preferences of founders are likely to differ from those of successors (e.g., Block, 2012). Moreover, scholars have argued that owner-managers from later generations focus more than founders on harvesting the firm and on personal wealth (Dyer and Handler, 1994). Sixth, I controlled for whether the firm was part of the owner-manager's personal pension plan. Owner-managers who view the firm as an important component of their retirement provisions might have higher expectations for the transaction price. Seventh, I controlled for the owner-manager's gender $($ male $=0$, female $=1)$. Female entrepreneurs have been shown to rely on different decision-making criteria than their male counterparts. For example, they are more likely to prioritize certain non-monetary aspects when considering a business exit (Justo and DeTienne, 2008). Lastly, I included a dummy variable indicating whether the incumbent would exit his or her business mainly for age and/or health reasons $(=1)$ or for other reasons $(=0)$, as the motivation for an exit might affect expectations for the transaction price.

\subsection{Statistical Analyses}


As the dependent variable is ordinal, an ordered regression model is appropriate (Long, 2002;

Greene, 2003). I used a probit link function (Cook et al., 2012), because the results of the parallel-line tests suggested that this best fits the data. However, the results did not significantly differ when using a logit link function instead of a probit link. To scrutinize the robustness of the findings, I carried out an additional set of OLS regressions. The results of those analyses will be shown in the next section.

\section{Results}

\subsection{Descriptive Data}

Table 1 presents descriptive statistics as well as a correlation matrix for all of the variables used in the models. In general, the correlations are low to moderate. Furthermore, I examined the variance inflation factors of the estimation variables. The variance inflation factors (see last columns in Tables 3 and 5) do not exceed 1.727 and are thus below the generally established threshold of 10 (Hair et al., 2006; Tabachnick and Fidell, 1996).

Insert Table 1 about here

A descriptive analysis of the data offers several initial insights into the extent of the emotionalpricing component (see Table 2 for numbers and an explanation of underlying assumptions). On average, owner-managers intend to sell their firm at a discount of $11 \%$ (sale to another firm) to $50 \%$ (FBO). Prospective discounts for MBOs and MBIs are $26 \%$ and $17 \%$, respectively. However, the data from the sample used for the post-hoc tests reveal that the actual emotional pricing component is lower for FBOs (42\%); similar for MBOs (26\%); and higher for MBIs to familiar people (36\%), MBIs to strangers $(26 \%)$, and for sales to other firms $(22 \%)$. These findings are interpreted and discussed in the discussion section (section 6).

Insert Table 2 about here 


\subsection{Results of the Ordered Probit Model}

The results of the ordered probit model are provided in columns 2-3 in Table 3.

Insert Table 3 about here

Model 1 includes only the control variables. A view of the firm as part of the pension plan is positively and significantly related to transaction-price expectations (and, thus, negatively related to emotional pricing; $\mathrm{p}<.05)$. "Age and/or health reasons" as the main reason for a firm's sale is negatively related to the intended transaction price $(\mathrm{p}<.001)$.

The independent variables are added in Model 2. H1 is supported as tenure is significantly and negatively correlated with transaction-price expectations $(\mathrm{p}<.05)$. In addition, Model 2 shows that FBOs $(\mathrm{p}<.001)$ and MBOs $(\mathrm{p}<.05)$ are associated with significantly lower expected transaction prices, while sales to another firm $(\mathrm{p}<.01)$ are associated with significantly higher expected transaction prices when compared to the baseline (i.e. exit type not yet decided). MBIs are positively but insignificantly related to transaction-price expectations. These findings provide initial support for H2. An ANOVA-based contrast analysis ${ }^{5}$ with expected transaction price as the dependent variable confirms the presence of significant $(p<.05)$ differences among all four intended paths (see Table 2 for mean values). In addition, in Model 2, firm performance is positively and significantly related to expectations for the transaction price $(\mathrm{p}<.001)$, which supports H3. Significant differences in the log likelihoods confirm the superiority of Model 2. The pseudo- $\mathrm{R}^{2}$ (Nagelkerke) of Model 2 is $21.6 \%$.

Given the non-linear nature of the regression model, coefficients represent odds and cannot be interpreted as marginal effects of the independent variable on the dependent variable. An

\footnotetext{
${ }^{5}$ Results can be obtained from the author upon request.
} 
analysis using the Stata function "prvalue" in the spost package ${ }^{6}$ reveals the following: $43 \%$ of CEOs with a one-year tenure as CEO intend to provide a discount of at least $20 \%$. This probability increases to $50 \%$ for CEOs with 20 years of tenure and $57 \%$ for CEOs with 40 years of tenure. When firm performance is assessed as excellent (value 7 on the above described scale from 1-7), the probability that a CEO intends to provide at least $20 \%$ discount is $36 \%$, at average performance (value 3.5 ) the probability is $56 \%$, and for inferior performance (value 1 ) the probability rises to $70 \%$. A planned transfer within the family increases the willingness to provide $20 \%$ discount or more by 34 percentage points. An MBO increases the willingness to give such discount by 12 percentage points and an intended sale to another firm decreases it by 17 percentage points.

Insert Table 3 about here

\subsection{Robustness Test-Linear Regression}

On the assumption that the dependent variable serves as a discrete measure for an underlying continuous variable (see discussion of Winship and Mare, 1984: 513), I ran a set of OLS regressions with the owner-manager's transaction-price expectations as the dependent variable (for an example, see Hamidi et al., 2008). The results of this post-hoc test (see columns 4-6 in Table 3) are in line with the findings of the ordered probit calculations. In addition to the significant results described in section 5.2, the OLS regression shows a negative and moderately significant relationship between family firm status and intended transaction price $(\mathrm{p}<.1)$. However, this association becomes insignificant when the independent variables are added.

\subsection{Post-Hoc Test-Retrospective Sample}

\footnotetext{
${ }^{6} \mathrm{http}: / /$ www.indiana.edu/ jslsoc/spost.htm.
} 
The results presented above can be perceived as reflections of intended behaviors (Ajzen, 1991). However, the theory of planned behavior has been challenged and criticized because planned behavior does not always result in action. Therefore, intentions may not be reliable predictors of actual behavior (Armitage and Conner, 1999). As this might limit the contribution of the findings presented here, I performed a post-hoc test, which scrutinizes some of my findings based on a sample of recent entrepreneurial exits. As described in the section on data collection, I identified 523 actual entrepreneurial exit processes in the overall sample, 455 of which provided information on emotional pricing (measured as "1 minus the relative transaction price," with the relative transaction price being the ratio of the transaction price to real value of the firm). I used this sub-sample to undertake another set of ordered and linear regressions.

To measure the dependent variable — relative transaction price - I used the same scale as described in the methodology section (3.2). However, I asked for the actual transaction price relative to real firm value rather than the expected transaction price. To measure the independent variable, "financial performance," I relied on a single item with a five-point Likert scale. The respondent was asked to assess the firm's performance relative to its peers at the time of transfer. Due to potential retrospective biases, I utilized a five-point scale rather than a seven-point scale, and I relied on a single-item measure rather than a multi-item measure. To measure the closeness of the relationship between the successor and the owner-manager at the time of transfer, I asked the respondent to describe his or her relationship with the predecessor at the time of transfer. For this measure, respondents could choose among the following options: (1) child, (2) spouse, (3) other relative, (4) employee, (5) friend, (6) business partner, and (7) no relationship. Options 1, 2, and 3 were summarized as FBOs. 
I used the year of the firm's foundation, a family-firm dummy, industry, size of the firm (measured as the number of full-time employees), ${ }^{7}$ the predecessor's gender, the respondent's gender, and a dummy variable for the incumbent's motivation for withdrawal as control variables. The descriptive statistics (see Table 4) reveal only low to moderate levels of correlation. The highest VIF value is 1.439 , which indicates a low risk of multicollinearity (Hair et al., 2006).

Insert Table 4 about here

To test the effects of financial performance and exit-route choice on actual transaction prices, I ran a set of ordered regressions (see columns 2-3 in Table 5). I used the complementary log-log as link function, as this function best fit the data. However, the results do not change substantially when alternative link functions are used. Moreover, similar to the approach used for the prospective sample, I ran additional OLS regressions (see columns 4-6 in Table 5).

Models 1 and 3 contain only the control variables. Size is negatively and significantly $(\mathrm{p}<$ .05 for Model 1; $\mathrm{p}<.1$ for Model 3) related to transaction prices, and thus positively related to emotional pricing. The respondent's gender is negatively and significantly related to transaction prices ( $\mathrm{p}<.1$ for Model 1; $\mathrm{p}<.05$ for Model 3), indicating that female successors might obtain higher discounts. Moreover, the OLS regression indicates a negative, significant association between industry and transaction-prices $(\mathrm{p}<.05)$.

The independent variables are added in Models 2 and 4. Firm performance at the time of transfer (as assessed by the successor) is not significantly related to the discount received. However, both models highlight a positive and significant effect of exit paths on emotional pricing, which provides additional support for H2. Interestingly, the significant effect of the

\footnotetext{
${ }^{7}$ Size, family firm status, and industry were measured for 2013 rather than at the time of ownership transfer.
} 
respondent's gender revealed in Model 1 and 3 disappears when the independent variables are added. In the ordinal regression (Model 2), family firm and the predecessor's gender are significantly related to emotional pricing ( $\mathrm{p}<.1$ for both variables). While transaction prices (relative to the firms' real values) tend to be higher in family firms, female predecessors appear to provide greater discounts. The statistics reveal the superiority of Models 2 and 4 relative to Models 1 and 3.

Insert Table 5 about here

\section{Discussions}

\subsection{Theoretical and Empirical Contributions}

I utilize a survey of Swiss SMEs to investigate the prevalence and antecedents of ownermanagers' non-economic considerations in the context of intended firm sales. The results show that owner-managers are willing to provide substantial discounts to their successors, and that the extent of this "emotional-pricing component" depends on such factors as perceived firm performance, managerial tenure within the firm, and the relationship ("familiarity" or "closeness") between the owner-manager and the successor.

The finding that private SMEs are traded at a discount (see Table 2, retrospective sample) resonates with previous empirical results (Granata and Chirico, 2010; Officer, 2007). However, this discount has typically been attributed to buyers' undervaluations of private firms and to buyers' negotiation skills (Granata and Chirico, 2010). The research design utilized here, which focuses on the owner-managers of SMEs (see Table 2), reveals that this is only part of the story. A large part of those discounts cannot be attributed to the negotiation power of the successor but is instead rooted in the owner-manager's own perspectives. This finding has important implications for future studies on transaction prices in the business-transfer context, as it suggests 
that such studies need to include the owner-manager's price expectations, especially "emotional pricing." To date, this has been an under-investigated research construct.

I argue that owner-managers' willingness to provide discounts to successors is rooted in non-economic considerations. As such, the study builds on scholarly predictions regarding the role of non-economic considerations in the entrepreneurial life cycle, especially the exit process (DeTienne, 2010). Previous research has pointed to the role of owner-managers' emotions when leading the firm (Cardon et al., 2005a) or their grief after a firm's failure (Shepherd et al., 2009; Jenkins et al., 2014). This research extends extant knowledge by theorizing and providing empirical support that the non-economic aspect also affects owner-managers' price expectations. In this regard, the theoretical argumentation and the empirical findings contradict the widespread belief that wealth creation in the form of transaction-price maximization is the sole and ultimate goal of entrepreneurs (Petty, 1997; Certo et al., 2001). Instead, the findings presented in this article provide indirect quantitative support for Graebner and Eisenhardt's (2004) propositions that owner-managers strive to find the "best" successor rather than to maximize the transaction price.

Moreover, this study makes an important contribution to the emerging stream of literature that strives to explain entrepreneurial exit phenomena based on behavioral finance (Wennberg et al., 2010; Sandri et al., 2010). Building on behavioral finance theories, I argue that ownermanagers do not fully act as homo oeconomicus but are driven by bounded rationality (Cyert and March, 1963), especially loss aversion (Kahneman and Tversky, 1979). Perceptions of inferior firm performance (an aspect referring to the seller's framing), a long relationship with and attachment to the firm (an important temporal aspect), and a "distant" vs. "familiar" relationship with the successor (which is closely related to trust) affect the owner-manager's fear of loss. As a result, such factors enhance his or her willingness to provide substantial discounts in order to 
increase the pool of candidates and mitigate the perceived non-financial losses associated with an entrepreneurial exit ("emotional pricing"). Thereby, I build on knowledge found in the familyownership context (Gómez-Mejía et al., 2007; Berrone et al., 2012) and extend prior work by arguing that the decisions and intentions of owner-managers are not only affected by the potential loss of tangible (financial) assets but also by the potential loss of intangible assets, such as information about the firm and the possibility of further influencing firm behavior.

This extension of behavioral finance theory is important because it allows us to resolve a seemingly stark contrast between the findings presented here and findings on transaction-price expectations generated from behavioral finance studies (Sevdalis et al., 2009). On the basis of prospect theory (Kahneman and Tversky, 1979), behavioral finance scholars argue that prolonged ownership leads to a reluctance to let go and, ultimately, to higher transaction-price expectations (endowment effect; Kahneman et al., 1991; Carmon and Ariely, 2000) rather than an emotional discount, as revealed by this study. The difference lies in the objects to be transferred. Experiment-based studies conducted in the fields of behavioral economics typically focus on the valuation of consumer goods (e.g., pens or cups). It is safe to assume that owners of such objects might desire to keep them in their possession, but they are unlikely to worry about those objects' futures or their own ability to remain informed about what happens to a consumer good after it is sold, or to attempt to influence its destiny. In contrast, a sale of a business is a much more complex and multi-facet phenomenon. Owner-managers may not only feel reluctant to let go of their businesses (an endowment effect that, when examined in isolation, might appear to increase transaction-price expectations; see discussions of the family firm's "emotional value" by Astrachan and Jaskiewicz, (2008) and Zellweger and Astrachan, (2008)) but also care about the firm's future and their own role in the long-term scenario (a desire that ultimately results in a willingness to provide discounts). Given the complexity arising from the nature of the "transfer 
object," entrepreneurial exit scholars need to be particularly careful when integrating concepts found in behavioral theories. In particular, they should include the owner-managers' concerns about the firm's future in their theory building.

The hypotheses and empirical evidence presented here shed light on the antecedents of emotional pricing. For instance, the results from the prospective sample show that the transaction-price intentions of owner-managers change over time ${ }^{8}$. This can be interpreted as additional support for the suggestion that non-economic aspects become more important over time (Dehlen et al., 2014; DeTienne, 2010). This study extends prior knowledge by linking emotional attachment to an increased focus on loss aversion and by discussing how transactionprice expectations are affected by such attachments.

In addition, the owner-manager's familiarity with the successor is an important determinant of emotional pricing in both samples (see support for $\mathrm{H} 2$ from both samples). A closer examination of the descriptive statistics provides additional important insights. For example, emotional-pricing components for MBIs differ substantially depending on whether the familyand firm-external individual is a "friend" or a stranger. In fact, roughly $50 \%$ of the MBI successors in the sample had some tie to the incumbent owner-manager prior to the business transfer. This indicates that future research should analyze the characteristics of specific MBIs rather than treat MBIs as a homogenous group.

The findings related to Hypothesis 3 extend prior work in the field of entrepreneurial exits (Wennberg et al., 2010) and provide a more nuanced understanding of the relationship between performance and entrepreneurial exits. In particular, they indicate that discrepancies between performance and expectations, which have been shown to affect firm behavior in several contexts (e.g., Chrisman and Patel, 2012), are also relevant in entrepreneurial exits. Notably, the effect of

\footnotetext{
${ }^{8}$ Corresponding data is not available for the retrospective sample.
} 
financial performance (H3) is significant for the prospective sample but insignificant for the retrospective sample. In line with critics of planned behavior theory (Armitage and Conner, 1999), this might indicate substantial differences between planned and actual entrepreneurial behavior. Another explanation might be methodological. For instance, an outsider's assessment of the firm's performance at the time of transfer might be distorted by retrospective bias (Janson, 1990) or by self-serving bias (Bradley, 1978). Moreover, the different results for the two samples might be explained by the argument that it is the owner-manager's perception of financial performance that drives his or her loss aversion. That perception might differ substantially from the firm's objective performance. The non-significance of firm performance in the retrospective sample might thus serve as cautious hint that it is indeed the perceived firm performance, rather than actual performance, that drives emotional pricing.

While industry has no significant effect in terms of intended prices, it has a significant effect on actual transfers (in OLS). Discounts are typically higher in service sectors than in production sectors. This observation may be explained by the higher proportion of immaterial assets in service firms. Furthermore, size exerts a negative and significant effect on actual transaction prices, ${ }^{9}$ such that the larger the business, the lower the transaction price relative to the real value. One possible explanation for this observation, which is also supported by anecdotal stories shared by Swiss practitioners, is that owner-managers of SMEs, especially those in rural areas, are challenged by the low "supply" of willing and capable successors who are able to finance a transaction. This challenge grows as the real value of the firm increases. Therefore, lowering the transaction price might be seen as a potential method for finding a successor. Notably, industry and size are only significant in the retrospective sample. This indicates that

\footnotetext{
${ }^{9}$ Note, however, that size of the firm was measured as of 2013 rather than at the time of transfer.
} 
these factors might not be considered by the owner-manager ex ante, but only come to the surface when a successor is present and uses his or her negotiation skills.

As expected, owner-managers who view their businesses as part of their pension plans are less willing to offer a discount to their successor. Moreover, the regression analysis shows that non-economic considerations in prospective pricing do not depend on the gender of the resigning owner-manager, but non-economic considerations in retrospective pricing are (marginally) affected by gender. In this regard, there is some initial evidence that female owner-managers offer larger discounts than their male counterparts do, and that female successors also receive higher discounts. Interestingly, the post-hoc test also provides weak evidence for increased transaction-price expectations in family firms. Moreover, the results from the control-only models show that owner-managers who resign due to health or age-related issues intend to offer larger discounts, but this effect disappears when the exit-path control is included.

\subsection{Implications for Practice}

The findings presented here have several important practical implications. To the best of my knowledge, this study is the first to carefully investigate owner-managers' transaction-price expectations and actual transaction-price discounts. On average, owner-managers consider selling their business at a $30 \%$ discount, with discount levels ranging from $11 \%$ to $50 \%$ depending on the expected exit path (see Table 2). A comparison of the prospective and retrospective data shows that actual discounts for family- and firm-externals are even higher, indicating the strong negotiation power of those parties. Despite its context-sensitivity, this data might serve as an anchor point for advisors, incumbent owner-managers, and potential successors in business-transfer situations.

Second, the findings reveal the importance of "familiarity with the resigning ownermanager." This finding might guide potential successors in their search and negotiation 
processes. Investing time and effort in getting to know the incumbent owner-manager and the firm, and in building trust and potential for longer-term relationships with the incumbent might ultimately pay off financially for the succession candidate. Moreover, potential successors should be aware that emotional discounts are lower if the incumbent owner-manager relies on the business for his or her retirement provision and higher for larger firms and firms in the service industry. On average, when the owner-manager has long been at the helm of the company and feels in financial distress, higher discounts can be expected. Moreover, gender aspects can further affect the level of emotional discounts.

For the resigning owner-managers, an awareness of how the perceived financial performance distorts transaction-price expectations is valuable. Owner-managers who are aware of this bias might be able to re-set their target-price expectations. To do so, they might build on the support of trusted advisors (Strike, 2013) who are trained and experienced in price setting and can provide an objective, outsider perspective. Discussions with such individuals might help the resigning owner-managers to agree on a transaction price that is neither too high nor too low. If the owner-manager's expectations regarding the transaction price are too high, potential successors might be alienated and ultimately withdraw from the transfer negotiations. As a consequence, the pool of potential successors will diminish as price expectations rise. In extreme cases, no adequate succession candidate will remain (Dehlen et al., 2014). On the other hand, if an owner-manager has low transaction-price expectations, then the actual transaction price might also be low, which could endanger his or her retirement funding. Moreover, an enhanced understanding of the non-economic processes affecting transaction-price considerations might encourage the owner to reflect on his or her underlying economic and non-economic goals for the exit, which could foster a smoother exit process.

\subsection{Limitations and Avenues for Future Research}


As with any empirical work, this study suffers from several limitations, which offer suggestions for future research. First, much of the investigation is based on self-reported intentions of ownermanagers rather than actual events. However, planned behavior is not necessarily converted into actual activities, although another empirical study (DeTienne and Cardon, 2012) shows that 70\% of their studied entrepreneurs ultimately exited in the intended way. To mitigate the limitations associated with this issue, I tested several of the hypotheses using a smaller sample of actual ownership transfers. While the results of those tests corroborate many of the findings, additional research that studies the phenomenon from a longitudinal perspective and that captures the owner-managers' pre-exit intentions and the actual transaction prices would be beneficial.

A longitudinal study would also help to overcome another limitation, which lies in the operationalization of the dependent variable. Given the scarcity of objective data on SMEs and the Swiss perception that financial data is highly sensitive, I asked respondents to indicate their expected transaction price as a percentage of real value. This request reflects the assumption that owners know the real value of their businesses. If this is not the case and if the owner-manager overestimates (underestimates) the firm's real value, then the actual monetary impact of the emotional pricing component might be lower (higher) than shown in this study.

In future studies on emotional pricing, it would be interesting to include additional control (e.g., lifestyle vs. income replacement vs. high-growth business (DeTienne, 2010) or entrepreneurial passion (Thorgren and Wincent, 2013)) and dependent variables, such as the likelihood of firm transfer, the incumbent's or the successor's satisfaction with the transfer, and post-transfer performance. Moreover, loss aversion might not be the only determinant of an owner-manager's transaction-price expectations. Such pricing might also depend on certain aspects of the owner-manager's personality, such as his or her self-efficacy (Bandura, 1982) or his or her regulatory focus (Higgins, 1998), both of which have been found to affect 
entrepreneurial behavior (Brockner et al., 2004; Tumasjan and Braun, 2012; Hmieleski and Corbett, 2008).

Reverse causality might be a concern with regard to Hypothesis 2 if we argue that the expected target price can affect the targeted exit path. For instance, owner-managers desiring a high transaction price might opt to sell the business to an external person rather than to someone within the family. I attempted to mitigate at least some of this risk by inserting a control variable for the owner's future financial dependence on the firm and its proceeds. However, additional research is required. Moreover, limitations arise from the sample used in the study. As discussed earlier, the response rate was relatively low. For this reason, I carefully considered the risk of non-response bias and the representativeness of the sample for the population of Swiss SMEs.

\section{Conclusion}

Non-economic considerations play a crucial role in entrepreneurial processes, especially in entrepreneurial exits. This study contributes to our understanding of how owner-managers' noneconomic considerations - their fear of losing access to information on the firm, their concerns about losing their influence on the firm, and their interests in the firm's future - are related to their "emotional pricing" when they wish to sell their businesses. This improved understanding of owner-managers' emotional pricing intentions is important for research and practice, as emotional pricing might lead to a substantial deviations between market values and transaction prices, which can subsequently affect important exit-outcome variables. 


\section{REFERENCES}

Ajzen I. (1991) The theory of planned behavior. Organizational behavior and human decision processes 50: 179-211.

Ariely D, Huber J and Wertenbroch K. (2005) When do losses loom larger than gains? Journal of Marketing Research: 134-138.

Armitage CJ and Conner M. (1999) The theory of planned behaviour: Assessment of predictive validity and'perceived control. British journal of social psychology 38: 35-54.

Astrachan JH and Jaskiewicz P. (2008) Emotional returns and emotional costs in privately held family businesses: Advancing traditional business valuation. Family Business Review 21: 139-149.

Baik B, Kang J-K and Morton R. (2007) Earnings management in takeovers of privately held targets. Available at SSRN 1013639.

Bandura A. (1982) Self-efficacy mechanism in human agency. American Psychologist 37: 122.

Bane WT and Neubauer FF. (1981) Diversification and the failure of new foreign activities. Strategic Management Journal 2: 219-233.

Barber B and Odean T. (2000) The courage of misguided convictions: The trading behavior of individual investors. Working paper available at SSRN 219175.

Barberis N and Thaler R. (2003) A survey of behavioral finance. Handbook of the Economics of Finance 1: $1053-1128$.

Battisti M and Okamuro H. (2010) Selling, passing on or closing? Determinants of entreprneurial intentions on exit modes. Massey U. College of Business Research Paper No. 27.

Berrone P, Cruz C and Gómez-Mejía LR. (2012) Socioemotional wealth in family firms: Theoretical dimensions, assessment approaches, and agenda for future research. Family Business Review 25: $258-279$.

Block JH. (2012) R\&D investments in family and founder firms: An agency perspective. Journal of Business Venturing 27: 248-265.

Bradley GW. (1978) Self-serving biases in the attribution process: A reexamination of the fact or fiction question. Journal of Personality and Social Psychology 36: 56.

Brockner J, Higgins ET and Low MB. (2004) Regulatory focus theory and the entrepreneurial process. Journal of Business Venturing 19: 203-220.

Cardon MS, Wincent J, Singh J, et al. (2005a) Entrepreneurial passion: The nature of emotions in entrepreneurship. Academy of Management Proceedings. Academy of Management, G1-G6.

Cardon MS, Zietsma C, Saparito P, et al. (2005b) A tale of passion: New insights into entrepreneurship from a parenthood metaphor. Journal of Business Venturing 20: 23-45.

Carmon $\mathrm{Z}$ and Ariely D. (2000) Focusing on the forgone: How value can appear so different to buyers and sellers. Journal of Consumer Research 27: 360-370.

Certo ST, Covin JG, Daily CM, et al. (2001) Wealth and the effects of founder management among IPOstage new ventures. Strategic Management Journal 22: 641-658.

Chrisman JJ and Patel P. (2012) Variations in R\&D investments of family and non-family firms: Behavioral agency and myopic loss aversion perspectives. Academy of Management Journal 55: 976-997.

Chua JH, Chrisman JJ and Sharma P. (1999) Defining the family business by behavior. Entrepreneurship Theory and Practice 23: 19-39.

Coad A. (2013) Death is not a success: Reflections on business exit. International Small Business Journal: 0266242612475104.

Cook GA, Pandit NR and Milman D. (2012) A resource-based analysis of bankruptcy law, SMEs and corporate recovery. International Small Business Journal 30: 275-293.

Cooney JW, Moeller T and Stegemoller M. (2009) The underpricing of private targets. Journal of Financial Economics 93: 51-66.

Cruz CC, Gómez-Mejía LR and Becerra M. (2010) Perceptions of benevolence and the design of agency contracts: CEO-TMT relationships in family firms. Academy of Management Journal 53: 69-89.

Cyert RM and March JG. (1963) A behavioral theory of the firm, Englewood Cliffs, NJ: Prentice-Hall.

Dehlen T, Zellweger T, Kammerlander N, et al. (2014) The role of information asymmetry in the choice of entrepreneurial exit routes. Journal of Business Venturing 29: 193-209. 
Deshpandé R, Farley JU and Webster Jr FE. (1993) Corporate Culture Customer Orientation, and Innovativeness in Japanese Firms: A Quadrad Analysis. Journal of Marketing 57.

DeTienne D and Chirico F. (in press) Exit Strategies in Family Firms: How Socioemotional Wealth drives the Threshold of Performance. Entrepreneurship: Theory \& Practice.

DeTienne DR. (2010) Entrepreneurial exit as a critical component of the entrepreneurial process: Theoretical development. Journal of Business Venturing 25: 203-215.

DeTienne DR and Cardon M. (2012) Impact of founder experience on exit intentions. Small Business Economics 38: 351-374.

Dyer WG and Handler W. (1994) Entrepreneurship and family business: Exploring the connections. Entrepreneurship Theory and Practice 19: 71-71.

Feldman SJ. (2005) Principles of private firm valuation: John Wiley \& Sons.

Geerts A, Herrings W and Peek M. (2004) Change of ownership creates new prospects in SME sector. SME Special 2004.

Genesove D and Mayer C. (2001) Loss aversion and seller behavior: Evidence from the housing market. The Quarterly Journal of Economics 116: 1233-1260.

Geneste LA and Galvin P. (2013) Trust and knowledge acquisition by small and medium-sized firms in weak client-firm exchange relationships. International Small Business Journal: 0266242613497379.

Gimeno J, Folta TB, Cooper AC, et al. (1997) Survival of the fittest? Entrepreneurial human capital and the persistence of underperforming firms. Administrative Science Quarterly: 750-783.

Gómez-Mejía LR, Takács Haynes K, Núnez-Nickel M, et al. (2007) Socioemotional wealth and business risks in family-controlled firms: Evidence from Spanish olive oil mills. Administrative Science Quarterly 52: 106-137.

Graebner ME and Eisenhardt KM. (2004) The seller's side of the story: Acquisition as courtship and governance as syndicate in entrepreneurial forms. Administrative Science Quarterly 49: 366-403.

Granata D and Chirico F. (2010) Measures of value in acquisitions: Family versus nonfamily firms. Family Business Review 23: 341-354.

Greene WH. (2003) Econometric analysis, Upper Saddle River, NY: Prentice-Hall.

Greve HR. (2003) A behavioral theory of R\&D expenditures and innovations: Evidence from shipbuilding. Academy of Management Journal 46: 685-702.

Greve HR. (2008) A behavioral theory of firm growth: Sequential attention to size and performance goals. Academy of Management Journal 51: 476-494.

Gulati R. (1995) Does familiarity breed trust? The implications of repeated ties for contractual choice in alliances. Academy of Management Journal 38: 85-112.

Hair JF, Black B, Babin B, et al. (2006) Multivariate data analysis: Prentice Hall.

Hambrick DC. (2007) Upper echelons theory: An update. Academy of Management Review 32: 334-343.

Hamidi DY, Wennberg K and Berglund H. (2008) Creativity in entrepreneurship education. Journal of Small Business and Enterprise Development 15: 304-320.

Higgins ET. (1998) Promotion and prevention: Regulatory focus as a motivational principle. Advances in experimental social psychology 30: 1-46.

Hmieleski KM and Corbett AC. (2008) The contrasting interaction effects of improvisational behavior with entrepreneurial self-efficacy on new venture performance and entrepreneur work satisfaction. Journal of Business Venturing 23: 482-496.

Howorth C, Westhead P and Wright M. (2004) Buyouts, information asymmetry and the family management dyad. Journal of Business Venturing 19: 509-534.

Howorth C, Wright M and Westhead P. (2007) Succession, professionalization and the staying power of "familiness": a longitudinal study of management buyouts of family firms Frontiers of Entrepreneurship Research 27: 1-15.

Hsu DK. (2013) 'This is my venture!'The effect of psychological ownership on intention to reenter entrepreneurship. Journal of Small Business \& Entrepreneurship 26: 387-402.

Huybrechts J, Voordeckers W and Lybaert N. (2013) Entrepreneurial Risk Taking of Private Family Firms The Influence of a Nonfamily CEO and the Moderating Effect of CEO Tenure. Family Business Review 26: 161-179. 
Janson C-G. (1990) Retrospective data, undesirable behavior, and the longitudinal perspective. Data quality in longitudinal research: 100-121.

Jenkins AS, Wiklund J and Brundin E. (2014) Individual responses to firm failure: Appraisals, grief, and the influence of prior failure experience. Journal of Business Venturing 29: 17-33.

Johnson-George C and Swap WC. (1982) Measurement of specific interpersonal trust: Construction and validation of a scale to assess trust in a specific other. Journal of Personality and Social Psychology 43: 1306.

Justo R and DeTienne DR. (2008) Family situation and the exit event: An extension of threshold theory. Frontiers of Entrepreneurship Research 28: 1-13.

Kahneman D, Knetsch JL and Thaler RH. (1991) Anomalies: The endowment effect, loss aversion, and status quo bias. The journal of economic perspectives: 193-206.

Kahneman D and Tversky A. (1979) Prospect theory: An analysis of decision under risk. Econometrica 47: 263-291.

Kellermanns FW, Eddleston K, Barnett T, et al. (2008) An exploratory study of family member characteristics and involvement: Effects on entrepreneurial behavior in the family firm. Family Business Review 21: 1-14.

Knetsch JL. (1989) The endowment effect and evidence of nonreversible indifference curves. The American Economic Review: 1277-1284.

König A, Kammerlander N and Enders A. (2013) The family innovator's dilemma: how family influence affects the adoption of discontinuous technologies by incumbent firms. Academy of Management Review 38: 418-441.

Kumar N, Stern LW and Anderson JC. (1993) Conducting interorganizational research using key informants. Academy of Management Journal 36: 1633-1651.

Kyle AS, Ou-Yang H and Xiong W. (2006) Prospect theory and liquidation decisions. Journal of Economic Theory 129: 273-288.

Long JS. (2002) Regression models for categorical and limited dependent variables, Thousand Oaks, CA: Sage.

Luo X and Chung C-N. (2005) Keeping It all in the Family: The Role of Particularistic Relationships in Business Group Performance during Institutional Transition. Administrative Science Quarterly 50: 404-439.

Mishina Y, Dykes BJ, Block ES, et al. (2010) Why "good" firms do bad things: The effects of high aspirations, high expectations, and prominence on the incidence of corporate illegality. Academy of Management Journal 53: 701-722.

Morris MH and Williams RO. (1997) Correlates of success in family business transitions. Journal of Business Venturing 12: 385-401.

Naldi L, Cennamo C, Corbetta G, et al. (2013) Preserving socioemotional wealth in family firms: Asset or liability? The moderating role of business context. Entrepreneurship Theory and Practice 37: 1341-1360.

Neumann LJ and Morgenstern O. (1947) Theory of games and economic behavior: Princeton university press Princeton, NJ.

Niedermeyer C, Jaskiewicz P and Klein SB. (2010) 'Can't get no satisfaction?'Evaluating the sale of the family business from the family's perspective and deriving implications for new venture activities. Entrepreneurship and Regional Development 22: 293-320.

Odean T. (1998) Are investors reluctant to realize their losses? The Journal of Finance 53: 1775-1798.

Officer MS. (2007) The price of corporate liquidity: Acquisition discounts for unlisted targets. Journal of Financial Economics 83: 571-598.

Olsen R. (2012) Trust: The Underappreciated Investment Risk Attribute. Journal of Behavioral Finance 13: 308-313.

Oppenheim AN. (1966) Questionnaire design and attitude measurement, New York: Free Press.

Osborne RL. (1991) Second-generation entrepreneurs: Passing the baton in the privately held company. Management Decision 29.

Parker SC, Storey DJ and Van Witteloostuijn A. (2010) What happens to gazelles? The importance of dynamic management strategy. Small Business Economics 35: 203-226. 
Petty J. (1997) Harvesting firm value: process and results. In: Sexton DL and Smilor RW (eds) Entrepreneurship 2000. Chicago: Upstart.

Pierce JL, Kostova T and Dirks KT. (2001) Toward a theory of psychological ownership in organizations. Academy of Management Review 26: 298-310.

Plehn-Dujowich J. (2010) A theory of serial entrepreneurship. Small Business Economics 35: 377-398.

Podsakoff PM, MacKenzie SB, Lee J-Y, et al. (2003) Common method biases in behavioral research: A critical review of the literature and recommended remedies. Journal of Applied Psychology 88: 879-903.

Podsakoff PM and Organ DW. (1986) Self-reports in organizational research: Problems and perspectives. Journal of Management 12: 531-544.

Pratt SP, Reilly RF and Schweihs RP. (2000) Valuing a business: McGraw-Hill.

Quigley TJ and Hambrick DC. (2012) When the former CEO stays on as board chair: effects on successor discretion, strategic change, and performance. Strategic Management Journal 33: 834-859.

Reinartz W, Krafft M and Hoyer WD. (2004) The customer relationship management process: its measurement and impact on performance. Journal of Marketing Research 41: 293-305.

Sandri S, Schade C, Musshoff O, et al. (2010) Holding on for too long? An experimental study on inertia in entrepreneurs' and non-entrepreneurs' disinvestment choices. Journal of economic behavior \& organization 76 : 30-44.

Scholes L, Wright M, Westhead P, et al. (2007) Information sharing, price negotiation and management buy-outs of private family-owned firms. Small Business Economics 29.

Schulze WS, Lubatkin MH, Dino RN, et al. (2001) Agency relationships in family firms: Theory and evidence. Organization Science 12: 99-116.

Seidler J. (1974) On using key informants: A technique for collecting quantitative data and controlling measurement error in organization analysis. American Sociological Review 39: 816-831.

Sevdalis N, Harvey N and Bell A. (2009) Affective Equilibria in the Endowment Effect. The Journal of Behavioral Finance 10: 89-100.

Sharma P, Chrisman JJ and Chua JH. (2003) Predictors of satisfaction with the succession process in family firms. Journal of Business Venturing 18: 667-687.

Shepherd DA, Covin JG and Kuratko DF. (2009) Project failure from corporate entrepreneurship: Managing the grief process. Journal of Business Venturing 24: 588-600.

Shimizu K. (2007) Prospect theory, behavioral theory, and the threat-rigidity thesis: Combinative effects on organizational decisions to divest formerly acquired units. Academy of Management Journal 50: $1495-1514$.

Shleifer A. (2000) Inefficient markets: An introduction to behavioral finance: Oxford university press.

Stam E, Thurik R and Van der Zwan P. (2010) Entrepreneurial exit in real and imagined markets. Industrial and Corporate Change 19: 1109-1139.

Strike VM. (2013) The most trusted advisor and the subtle advice process in family firms. Family Business Review 26: 293-313.

Stryker S and Burke PJ. (2000) The past, present, and future of an identity theory. Social psychology quarterly.

Tabachnick BG and Fidell LS. (1996) Using multivariate statistics, New York: HarperCollins College Publishers.

Thorgren S and Wincent J. (2013) Passion and habitual entrepreneurship. International Small Business Journal: 0266242613487085.

Tumasjan A and Braun R. (2012) In the eye of the beholder: How regulatory focus and self-efficacy interact in influencing opportunity recognition. Journal of Business Venturing 27: 622-636.

Tversky A and Kahneman D. (1991) Loss aversion in riskless choice: A reference-dependent model. The Quarterly Journal of Economics 106: 1039-1061.

Ucbasaran D, Westhead P, Wright M, et al. (2010) The nature of entrepreneurial experience, business failure and comparative optimism. Journal of Business Venturing 25: 541-555.

Van Teeffelen L and Uhlaner LM. (2013) Firm Resource Characteristics and Human Capital as Predictors of Exit Choice: An Exploratory Study of SMEs. Entrepreneurship Research Journal 3: 84-108. 
Van Teeffelen L, Uhlaner LM and Driessen M. (2011) The importance of specific human capital, planning and familiarity in Dutch small firm ownership transfers: a seller's perspective. International Journal of Entrepreneurship and Small Business 14: 127-148.

Volery T, Bergmann H, Gruber M, et al. (2007) Global Entrepreneurship Monitor - Swiss Report. In: Gallen UoS (ed). St. Gallen, Switzerland.

Wennberg K and DeTienne DR. (2014) What do we really mean when we talk about 'exit'? A critical review of research on entrepreneurial exit. International Small Business Journal 32: 4-16.

Wennberg K, Wiklund J, DeTienne DR, et al. (2010) Reconceptualizing entrepreneurial exit: Divergent exit routes and their drivers. Journal of Business Venturing 25: 361-375.

Wennberg K, Wiklund J, Hellerstedt K, et al. (2011) Implications of intra-family and external ownership transfer of family firms: short-term and long-term performance differences. Strategic Entrepreneurship Journal 5: 352-372.

Winship C and Mare RD. (1984) Regression models with ordinal variables. American Sociological Review: 512-525.

Wong JTY and Hui ECM. (2008) The myth of property prices: on the psychology of sellers and buyers. Property Management 26: 171-190.

Zahra SA. (2003) International expansion of US manufacturing family businesses: The effect of ownership and involvement. Journal of Business Venturing 18: 495-512.

Zellweger TM and Astrachan JH. (2008) On the emotional value of owning a firm. Family Business Review 21: 347-363.

Zellweger TM, Kellermanns FW, Chrisman JJ, et al. (2012) Family control and family firm valuations by family CEOs: The importance of intentions for transgenerational control. Organization Science 23: 851-868. 


\section{TABLES}

Table 1: Means, Standard Deviations, and Pearson Correlations (Prospective Sample)

\begin{tabular}{|c|c|c|c|c|c|c|c|c|c|c|c|c|c|c|c|c|c|}
\hline & Variable & Mean & S.D. & 1 & 2 & 3 & 4 & 5 & 6 & 7 & 8 & 9 & 10 & 11 & 12 & 13 & 14 \\
\hline 1 & Emotional pricing & 5.16 & 2.08 & 1.000 & & & & & & & & & & & & & \\
\hline 2 & Co-owners & .38 & .49 & .080 & 1.000 & & & & & & & & & & & & \\
\hline 3 & Family firm & .84 & .36 & -.089 & -.549 & 1.000 & & & & & & & & & & & \\
\hline 4 & Industry & .44 & .49 & .029 & .042 & -.072 & 1.000 & & & & & & & & & & \\
\hline 5 & Size & 35.71 & 55.96 & -.043 & .060 & -.025 & -.149 & 1.000 & & & & & & & & & \\
\hline 6 & Retirement plan & .51 & .50 & .110 & -.027 & .067 & -.001 & -.075 & 1.000 & & & & & & & & \\
\hline 7 & Gender & .05 & .22 & -.021 & -.046 & -.001 & .121 & -.082 & .047 & 1.000 & & & & & & & \\
\hline 8 & Founder & .54 & .49 & .066 & .156 & -.120 & .218 & -.239 & .076 & .089 & 1.000 & & & & & & \\
\hline 9 & Exit reason & .64 & .47 & -.099 & -.010 & .026 & -.031 & .007 & -.039 & .049 & -.018 & 1.000 & & & & & \\
\hline 10 & Tenure & 20.48 & 11.00 & -.161 & -.098 & .139 & -.065 & .075 & .082 & -.054 & -.078 & .154 & 1.000 & & & & \\
\hline 11 & Performance & 4.59 & 1.10 & .051 & -.005 & -.018 & -.043 & .076 & -.004 & .017 & .054 & -.075 & -.019 & 1.000 & & & \\
\hline 12 & FBO & .41 & .49 & -.415 & -.234 & .296 & -.052 & .085 & -.018 & .018 & -.144 & .128 & .210 & .058 & 1.000 & & \\
\hline 13 & MBO & .16 & .36 & .058 & .252 & -.290 & -.001 & -.050 & .005 & -.055 & .117 & .004 & -.043 & .039 & -.364 & 1.000 & \\
\hline 14 & MBI & .10 & .29 & .141 & -.003 & -.003 & .115 & -.127 & .034 & .035 & .139 & .018 & -.034 & -.105 & -.273 & -.142 & 1.000 \\
\hline 15 & Sale to other firm & .09 & .28 & .195 & .087 & -.141 & -.009 & .021 & .036 & -.026 & .110 & -.134 & -.005 & .027 & -.267 & -.138 & -.104 \\
\hline
\end{tabular}

All correlations with an absolute value of more than .047 are significant at $\mathrm{p}<.05$. 
table 2: Emotional Pricing by Exit Path

\begin{tabular}{|c|c|c|c|c|}
\hline & FBO & MBO & MBI & SALE TO OTHER FIRM \\
\hline $\begin{array}{c}\text { Prospective sample- } \\
\text { average discount }\end{array}$ & $50 \%$ & $26 \%$ & $17 \%$ & $11 \%$ \\
\hline $\begin{array}{c}\text { Retrospective sample- } \\
\text { average discount }\end{array}$ & $42 \%$ & $26 \%$ & $\begin{array}{c}\text { Friend: } 30 \% \\
\text { Stranger: } 26 \%\end{array}$ & $22 \%$ \\
\hline
\end{tabular}

Note: This table is based on several assumptions. First, the categories in the questionnaire were translated into emotional pricing values as follows: Category ' 1 ': $0 \%,{ }^{\prime} 2$ ': $10 \%$, , '3': 30\%, '4': 50\%, '5': 70\%, '6': 90\%, '7': 100\%, '8': 100\%. Given the assumption that there intended prices equal market prices for those respondents who chose category 8 , the displayed discounts are likely to exaggerate the actual discounts. However, “' 8 ': $100 \%$ " is the best available assumption, as data on any requested premiums is lacking. Moreover, only $4.2 \%$ of all cases (48 in total) fall into that category 
TABle 3: Regression for Emotional-Pricing Intentions (Prospective SAMPLe)

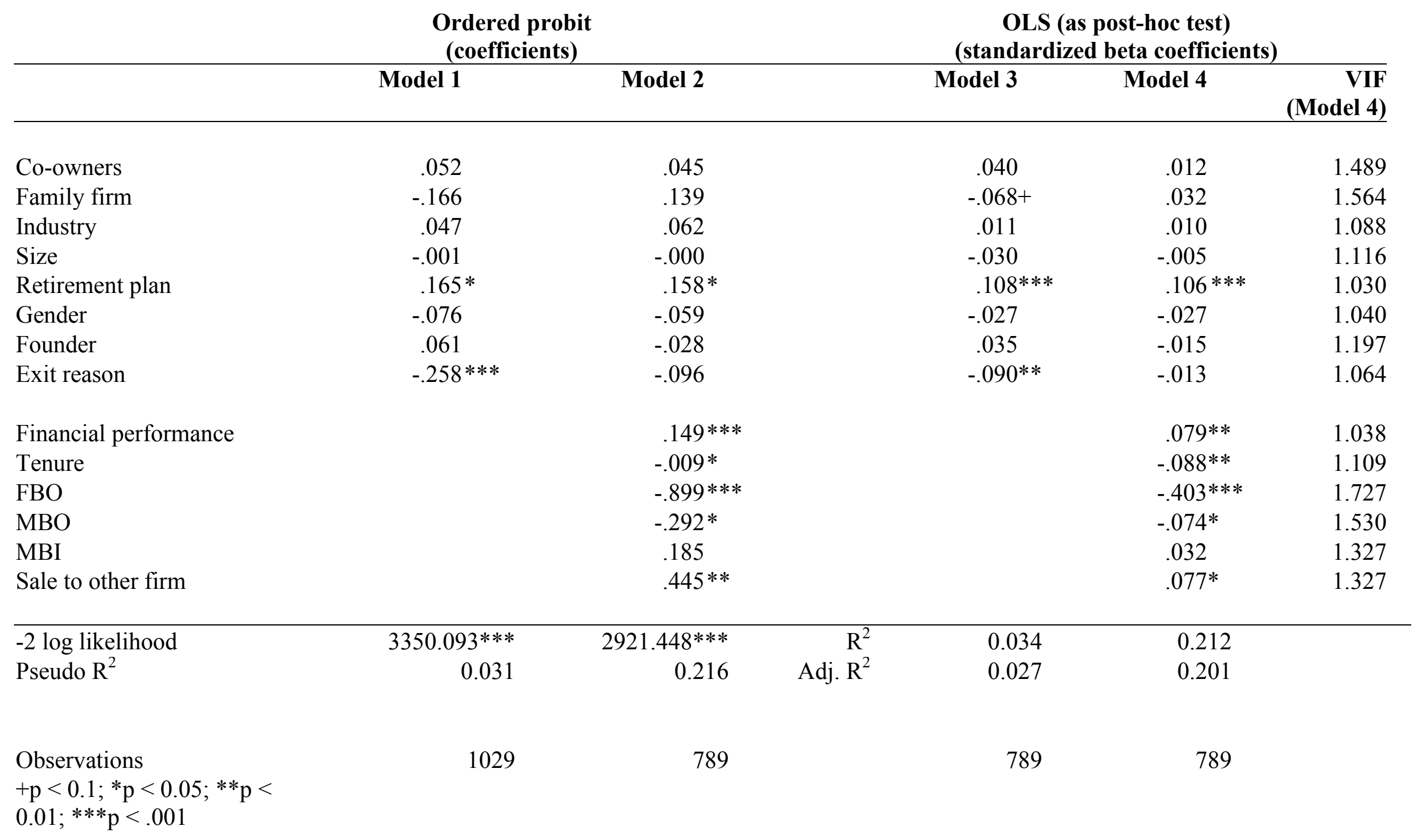


Table 4: Post-hoc Test: Means, Standard Deviations, and Pearson Correlations (Retrospective Sample)

\begin{tabular}{|c|c|c|c|c|c|c|c|c|c|c|c|c|c|c|c|}
\hline & & Mean & S.D. & 1 & 2 & 3 & 4 & 5 & 6 & 7 & 8 & 9 & 10 & 11 & 12 \\
\hline 1 & Emotional pricing & 5.06 & 2.21 & 1.000 & & & & & & & & & & & \\
\hline 2 & Family firm & .80 & .40 & -.019 & 1.000 & & & & & & & & & & \\
\hline 3 & Industry & .39 & .49 & -.124 & -.059 & 1.000 & & & & & & & & & \\
\hline 4 & Size & 38.20 & 59.55 & -.081 & -.036 & -.212 & 1.000 & & & & & & & & \\
\hline 5 & Firm foundation & 1963.75 & 40.10 & .066 & -.081 & .200 & -.288 & 1.000 & & & & & & & \\
\hline 6 & Gender of predecessor & .05 & .22 & -.126 & -.024 & .164 & -.073 & .084 & 1.000 & & & & & & \\
\hline 7 & Own gender & .06 & .23 & -.148 & .027 & .165 & -.088 & .063 & .246 & 1.000 & & & & & \\
\hline 8 & Exit reason & .58 & .49 & .037 & .117 & -.135 & -.012 & -.155 & -.038 & -.137 & 1.000 & & & & \\
\hline 9 & Firm performance & 2.8 & .99 & -.044 & .035 & -.032 & -.008 & -.066 & .018 & -.003 & .180 & 1.000 & & & \\
\hline 10 & $\mathrm{MBO}$ & .19 & .39 & .092 & -.216 & .044 & .024 & .034 & -.005 & -.050 & -.012 & .035 & 1.000 & & \\
\hline 11 & MBI_friend & .10 & .30 & .013 & -.070 & .077 & -.133 & .081 & .109 & .011 & .029 & .015 & -.164 & 1.000 & \\
\hline 12 & MBI_stranger & .19 & .39 & .092 & -.118 & .037 & -.002 & .170 & -.048 & .048 & -.130 & -.164 & -.240 & -.164 & 1.000 \\
\hline 13 & Sale to other firm & .10 & .30 & .111 & -.079 & .023 & -.042 & .142 & .003 & -.082 & -.193 & -.122 & -.166 & -.114 & -.166 \\
\hline
\end{tabular}

All correlations with absolute values of more than .077 are significant at $\mathrm{p}<0.05$. 
Table 5: Post-hoc Test: Ordinal And OLS Regression for EMotional Pricing (Retrospective SAMPLe)

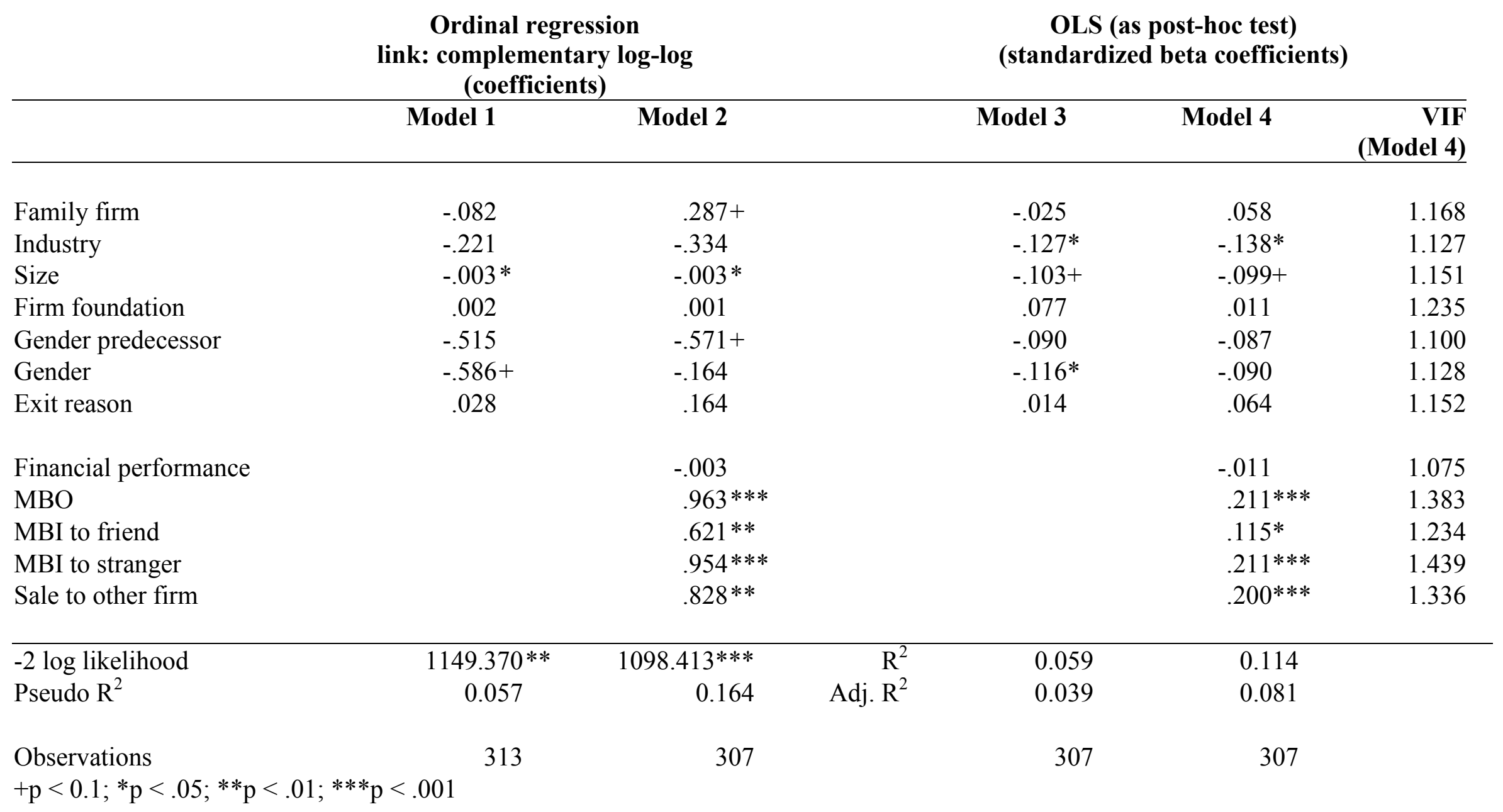

Ordinal regression results are independent of whether "financial performance" is treated as an ordinal or continuous variable. 